\title{
SUPPLEMENTARY MATERIAL FOR THE PAPER "A HIERARCHICAL BAYESIAN MODEL FOR INFERENCE OF COPY NUMBER VARIANTS AND THEIR ASSOCIATION TO GENE EXPRESSION"
}

\author{
By Alberto Cassese ${ }^{*}$, Michele Guindani ${ }^{\dagger}$ Mahlet G. Tadesse ${ }^{\ddagger}$ \\ FRANCESCO FALCIANI ${ }^{\S}$ AND MARINA VANNUCCI* \\ Rice University*, MD Anderson Cancer Center ${ }^{\dagger}$, Georgetown University ${ }^{\ddagger}$ and \\ University of Liverpool ${ }^{\S}$
}

MCMC steps. Here we describe our MCMC algorithm in detail. During the update of $\boldsymbol{R}$ (and of $\boldsymbol{\xi}$ ) we first select a list of gene expression, as rows of $\boldsymbol{R}$ (and a list of samples, as elements of a randomly selected column of $\xi$ ) and then update and accept/reject their individual values. For this, we first sample from a geometric distribution with probability $p_{R}$ (or $p_{\xi}$ ) and add the result to the index of the last selected gene expression (sample). If the resulting index is greater than $G$ (or $n$ ), then we discard the new value and stop, otherwise we add the new position to the list of selected gene expression (samples) and draw a new value from the geometric distribution. For the first draw, we simply consider the result as the position to be updated. The updates on $\eta_{j}, \sigma_{j}$, for $j=1, \ldots, 4$, and the transition matrix $\mathbf{A}$ follow Guha et al. (2008), though applied to all samples simultaneously. We recall below equations involved in the MCMC steps:

$$
\begin{aligned}
& \pi\left(r_{g m} \mid r_{g(m-1)}, r_{g(m+1)}, \boldsymbol{\xi}\right)=\gamma_{m} \frac{\Gamma(e+f) \Gamma\left(e+r_{g m}\right) \Gamma\left(f+1-r_{g m}\right)}{\Gamma(e+f+1) \Gamma(e) \Gamma(f)} \\
& +\sum_{j=1}^{2} \omega_{m}^{(j)} I_{\left\{r_{g m}=r_{g\left(m+(-1)^{j}\right.}\right\}} \text {. } \\
& f\left(\boldsymbol{Y}_{g} \mid \boldsymbol{\xi}, \boldsymbol{R}\right)=\frac{(2 \pi)^{-\frac{n}{2}}\left(\frac{c_{\mu}}{c_{\mu}+n}\right)^{\frac{1}{2}}\left(c_{\beta}\right)^{\frac{k_{g}}{2}} \Gamma\left(\frac{n+\delta}{2}\right)\left(\frac{d}{2}\right)^{\frac{\delta}{2}}}{\left|\boldsymbol{U}_{g}\right|^{\frac{1}{2}} \Gamma\left(\frac{\delta}{2}\right)\left(\frac{d+q_{g}}{2}\right)^{\left(\frac{n+\delta}{2}\right)}},
\end{aligned}
$$

Updating $R$. We give details on how to calculate the probability $\pi(\boldsymbol{R} \mid \boldsymbol{\xi})$ when updating $\boldsymbol{R}$ :

$$
\pi(\boldsymbol{R} \mid \boldsymbol{\xi})=\prod_{g=1}^{G} \pi\left(r_{g 1} \mid r_{g 2}, \boldsymbol{\xi}\right) \pi\left(r_{g M} \mid r_{g(M-1)}, \boldsymbol{\xi}\right) \prod_{m=2}^{M-1} \pi\left(r_{g m} \mid r_{g(m-1)}, r_{g(m+1)}, \boldsymbol{\xi}\right) .
$$


When calculating the ratio $\frac{\pi\left(\boldsymbol{R}^{\text {new }} \mid \boldsymbol{\xi}\right)}{\pi\left(\boldsymbol{R}^{\text {old }} \mid \boldsymbol{\xi}\right)}$ we need to consider only those quantities whose values change when a single element of $\boldsymbol{R}$ is updated. What follows is the description of the different scenarios that could occur when applying our MCMC update.

- Adding/deleting:

- If the selected element is not either the first or last CGH probe, three elements change their values (say, for example, that element $r_{g m}$ is selected): $\pi\left(r_{g m} \mid r_{g(m-1)}, r_{g(m+1)}, \boldsymbol{\xi}\right), \pi\left(r_{g(m-1)} \mid r_{g(m-2)}, r_{g m}, \boldsymbol{\xi}\right)$ and $\pi\left(r_{g(m+1)} \mid r_{g m}, r_{g(m+2)}, \boldsymbol{\xi}\right)$.

- If the selected element is either CGH probe 1 or $\mathrm{M}$, only two quantities change their values:

$$
\begin{aligned}
& * \pi\left(r_{g 1} \mid r_{g 2}, \boldsymbol{\xi}\right) \text { or } \pi\left(r_{g M} \mid r_{g(M-1)}, \boldsymbol{\xi}\right) ; \\
& * \pi\left(r_{g 2} \mid r_{g 1}, r_{g 3}, \boldsymbol{\xi}\right) \text { or } \pi\left(r_{g(M-1)} \mid r_{g(M-2)}, r_{g M}, \boldsymbol{\xi}\right) .
\end{aligned}
$$

- Swapping:

- Swap between adjacent elements; four quantities change their values (say, for example, that $r_{g m}$ get swapped with $r_{g(m-1)}$ ):

$$
\begin{array}{ll}
* & \pi\left(r_{g(m-2)} \mid r_{g(m-3)}, r_{g(m-1)}, \boldsymbol{\xi}\right) ; \\
* & \pi\left(r_{g(m-1)} \mid r_{g(m-2)}, r_{g m}, \boldsymbol{\xi}\right) ; \\
* & \pi\left(r_{g m} \mid r_{g(m-1)}, r_{g(m+1)}, \boldsymbol{\xi}\right) ; \\
* & \pi\left(r_{g(m+1)} \mid r_{g m}, r_{g(m+2)}, \boldsymbol{\xi}\right) .
\end{array}
$$

- Swap between "quasi-adjacent" elements, i.e., two elements that are two CGH probes positions apart. Five quantities get involved (say, for example, that $r_{g m}$ get swapped with $\left.r_{g(m-2)}\right)$ :

$$
\begin{aligned}
* & \pi\left(r_{g(m-3)} \mid r_{g(m-4)}, r_{g(m-2)}, \boldsymbol{\xi}\right) ; \\
* & \pi\left(r_{g(m-2)} \mid r_{g(m-3)}, r_{g(m-1)}, \boldsymbol{\xi}\right) ; \\
* & \pi\left(r_{g(m-1)} \mid r_{g(m-2)}, r_{g m}, \boldsymbol{\xi}\right) ; \\
* & \pi\left(r_{g m} \mid r_{g(m-1)}, r_{g(m+1)}, \boldsymbol{\xi}\right) ; \\
* & \pi\left(r_{g(m+1)} \mid r_{g m}, r_{g(m+2)}, \boldsymbol{\xi}\right) .
\end{aligned}
$$

- Swap between all other elements are just an Add and a Delete step.

Note that if the swap involves either $\mathrm{CGH}$ probe 1 or $\mathrm{M}$ then these quantities reduce by one. Equation (1) is used to calculate all quantities involved in the steps above.

Updating $\boldsymbol{\xi}$. With this update, when calculating the probability $\pi(\boldsymbol{R} \mid \boldsymbol{\xi})$ we need to look for changes in the values of $\boldsymbol{\gamma}, \boldsymbol{\omega}^{(1)}$ and $\boldsymbol{\omega}^{(2)}$. Suppose we change the value of the $m$-th element, then:

- We need to recalculate $\frac{1}{n} \sum_{i=1}^{n} I_{\left\{\xi_{i m}=\xi_{i(m-1)}\right\}}$ and $\frac{1}{n} \sum_{i=1}^{n} I_{\left\{\xi_{i m}=\xi_{i(m+1)}\right\}}$; 
- These quantities result in changes in the values of $\gamma_{m}, \omega_{m}^{(1)}, \omega_{m}^{(2)}, \gamma_{m-1}$, $\omega_{m-1}^{(1)}, \omega_{m-1}^{(2)}, \gamma_{m+1}, \omega_{m+1}^{(1)}, \omega_{m+1}^{(2)}$;

- We apply equation (1) to calculate the new values of $\pi\left(r_{g m} \mid r_{g(m-1)}, r_{g(m+1)}, \boldsymbol{\xi}\right)$, $\pi\left(r_{g(m-1)} \mid r_{g(m-2)}, r_{g m}, \boldsymbol{\xi}\right)$ and $\pi\left(r_{g(m+1)} \mid r_{g m}, r_{g(m+2)}, \boldsymbol{\xi}\right)$.

Equation (2) is then used to calculate $f\left(\boldsymbol{Y} \mid \boldsymbol{\xi}^{\text {new }}, \boldsymbol{R}\right)$ and $f\left(\boldsymbol{Y} \mid \boldsymbol{\xi}^{\text {old }}, R\right)$, while $f\left(x_{i m} \mid \xi_{i m}\right)$ is simply the density of a $N\left(\mu_{\xi_{i m}}, \sigma_{\xi_{i m}}^{2}\right)$, calculated in the current values of $\mu_{\xi_{i m}}$ and $\sigma_{\xi_{i m}}^{2}$.

Next, we focus on the ratio:

$$
\frac{\pi\left(\boldsymbol{\xi}^{\text {new }} \mid \boldsymbol{\xi}^{\text {old }}, \boldsymbol{A}\right) q\left(\boldsymbol{\xi}^{\text {old }} \mid \boldsymbol{\xi}^{\text {new }}\right)}{\pi\left(\boldsymbol{\xi}^{\text {old }} \mid \boldsymbol{\xi}^{\text {old }}, \boldsymbol{A}\right) q\left(\boldsymbol{\xi}^{\text {new }} \mid \boldsymbol{\xi}^{\text {old }}\right)},
$$

that can be factorized as

$$
\prod_{i=1}^{n} \frac{\pi\left(\xi_{i m}^{\text {new }} \mid \xi_{i(m-1)}^{\text {old }}, \xi_{i(m+1)}^{\text {old }}, \boldsymbol{A}\right) q\left(\xi_{i m}^{\text {old }} \mid \xi_{i m}^{\text {new }}\right)}{\pi\left(\xi_{i m}^{\text {old }} \mid \xi_{i(m-1)}^{\text {old }}, \xi_{i(m+1)}^{\text {old }}, \boldsymbol{A}\right) q\left(\xi_{\text {im }}^{\text {new }} \mid \xi_{i m}^{\text {old }}\right)} .
$$

The ratio of interest can be evaluated as $\frac{\pi\left(\xi_{i(m+1)}^{\text {old }} \mid \xi_{i m}^{\text {new }}, \boldsymbol{A}\right)}{\left.\pi\left(\xi_{i(m+1)}^{\text {old }}\right) \xi_{i m}^{\text {old }}, \boldsymbol{A}\right)}$, when $m \neq M$, and simply as 1 when $m=M$, by noting that $q\left(\xi_{\text {im }}^{\text {new }} \mid \xi_{\text {im }}^{\text {old }}\right)=\pi\left(\xi_{i m}^{\text {new }} \mid \xi_{i(m-1)}^{\text {old }}, \boldsymbol{A}\right)$, $\frac{\pi\left(\xi_{i m}^{\text {new }} \mid \xi_{i(m-1)}^{\text {old }}, \xi_{i(m+1)}^{\text {old }}, \boldsymbol{A}\right)}{\pi\left(\xi_{i m}^{\text {old }} \mid \xi_{i(m-1)}^{\text {old }}, \xi_{i(m+1)}^{\text {old }}, \boldsymbol{A}\right)}=\frac{\pi\left(\xi_{i(m+1)}^{\text {old }} \mid \xi_{i m}^{\text {new }}, \boldsymbol{A}\right) \pi\left(\xi_{i m}^{\text {new }} \mid \xi_{i(m-1)}^{\text {old }}, \boldsymbol{A}\right)}{\pi\left(\xi_{i(m+1)}^{\text {old }} \mid \xi_{i m}^{\text {old }}, \boldsymbol{A}\right) \pi\left(\xi_{i m}^{\text {old }} \mid \xi_{i(m-1)}^{\text {old }}, \boldsymbol{A}\right)}$, and considering that we update a single sample, sample $i$ in our example.

Updating $\eta$. Let $j=\{1,2,3,4\}$ be the label for the four different states, $\delta_{j}$ be the center of the truncated normal distributions in the prior specification of $\eta_{j}, n_{j}$ be the number of CGH in state $j, \bar{X}_{j}$ the mean of $X$ 's over those CGH probes that are in state $j$ and $\mathbf{I}_{j}$ denote the support of $\eta_{j}$. Specifically

$$
n_{j}=\sum_{m=1}^{M} \sum_{i=1}^{n} \mathbf{I}_{\left\{\xi_{i m}=j\right\}}, \quad \bar{X}_{j}=\frac{1}{n_{j}} \sum_{m=1}^{M} \sum_{i=1}^{n} X_{i m} \mathbf{I}_{\left\{\xi_{i m}=j\right\}} .
$$

The posterior probability for $\eta$ is:

$$
\pi\left(\eta_{j} \mid X, \text { rest }\right) \sim N\left(\nu_{j},\left(\theta_{j}^{2}\right)^{-1}\right) \mathbf{I}_{j}
$$

where $\theta_{j}=\tau_{j}^{-2}+n_{j} \sigma_{j}^{-2}$ and $\nu_{j}=\theta_{j}^{-2}\left(\delta_{j} \tau_{j}^{-2}+\bar{X}_{j} n_{j} \sigma_{j}^{-2}\right)$. 
Updating $\sigma^{2}$. Let $j=\{1,2,3,4\}$ be the label for the four different states, and $\mathbf{I}_{j}$ denote the support of $\sigma_{j}^{2}$, the posterior probability for $\sigma$ is:

$$
\pi\left(\sigma_{j}^{2} \mid X, r e s t\right) \sim I G\left(b_{j}+\frac{n_{j}}{2}, l_{j}+\frac{V_{j}}{2}\right) \mathbf{I}_{j}
$$

where $V_{j}=\sum_{m=1}^{M} \sum_{i=1}^{n}\left(X_{i m}-\mu_{j}\right)^{2} \mathbf{I}_{\left\{\xi_{i m}=j\right\}}$.

Updating A. Let's focus on a single row of the transition matrix $\mathbf{A}$, then the distribution of the states arises from a multinomial distribution (except for the first element of each sample), and the prior distribution of any row of the matrix is $\operatorname{Dir}\left(\phi_{1}, \phi_{2}, \phi_{3}, \phi_{4}\right)$. We follow Guha et al. (2008) and generate a proposal $\boldsymbol{A}^{\text {new }}$ from the distribution $a_{h} \mid$ rest $\sim \operatorname{Dir}\left(\phi_{1}+o_{h 1}, \phi_{2}+o_{h 2}, \phi_{3}+o_{h 3}, \phi_{4}+o_{h 4}\right)$, ignoring the marginal distribution of state $\xi_{1}$. We then accept the proposal with probability $\min \left[1, \prod_{i=1}^{n} \frac{\pi_{A^{n e w}}\left(\xi_{i 1}\right)}{\pi_{A^{\text {old }}}\left(\xi_{i 1}\right)}\right]$, where $\pi_{A}$ denotes the stationary distribution of the transition matrix $\boldsymbol{A}$.

Additional results for the simulations. For simulated scenario $1\left(\sigma_{\epsilon}=.1\right)$ with the independent prior, the empirical transition matrix corresponding to the simulated data and the estimated transition matrix were, respectively,

$$
\left[\begin{array}{cccc}
0.3513 & 0.6183 & 0.0216 & 0.0088 \\
0.1101 & 0.7762 & 0.1118 & 0.0019 \\
0.0089 & 0.6209 & 0.3267 & 0.0436 \\
0 & 0.6000 & 0.0586 & 0.3414
\end{array}\right] \quad\left[\begin{array}{ccccc}
0.3264 & 0.6417 & 0.0217 & 0.0102 \\
0.1027 & 0.7826 & 0.1038 & 0.0109 \\
0.0079 & 0.6202 & 0.3023 & 0.0695 \\
0.0008 & 0.6022 & 0.0461 & 0.3508
\end{array}\right]
$$

with the empirical transition matrix obtained by counting the number of changes from state $i$ to state $j$ that occur between adjacent positions in the true matrix $\boldsymbol{\xi}$. We note that in our simulation the data generating mechanism for $\boldsymbol{\xi}$ is based on randomly selecting $L$ columns, with some stretches of adjacent columns, therefore violating the stationarity assumption of the HMM chain. The results above, jointly with those shown in Section 4.2, suggest that our estimates are robust even in cases where the stationary assumption of the HMM is violated.

For simulated scenario 2, we generated the data by fixing the error variance $\sigma_{\epsilon}$ to a same value for every gene $g$, even though our proposed model does allow each gene to have its own variance. This is not restrictive, as, with real data, one can always perform the analysis on standardized data, i.e., with $\sigma_{\epsilon}=1$. We did however perform an additional simulation where we generated the data using standard deviations $\sigma_{\epsilon g}$ that vary with $g$. These were chosen by randomly selecting 100 genes from the set used in the case study and calculating their raw s.d.'s. These values were constrained to be in the range $[.1, .5]$, to facilitate the comparison with the 
simulation settings reported in the paper. Using an FDR threshold of .05, our model with a dependent prior resulted in specificity $=.99996$ and sensitivity $=.95$ for $\alpha=10$ and specificity $=.99998$ and sensitivity $=.85$ for $\alpha=50$, in line with the results from previous simulations. Inference on the HMM parameters was also comparable to the other simulated settings.

Additional results for the case study. Below we present a table that contains functions of mutations linked to the target pathways identified in our analysis (see Section 5 of the paper).

Table 1: Functions of mutations linked to the target pathways identified in our analysis (see Section 5 of the paper). Information extracted from the web based resource GeneCards (http://www.genecards.org).

\begin{tabular}{|c|c|c|}
\hline Official gene symbol & Name & Function \\
\hline MTERFD1 & $\begin{array}{l}\text { MTERF domain } \\
\text { containing } 1\end{array}$ & $\begin{array}{l}\text { Mitochondrial transcription termination factor } \\
\text { Binds promoter DNA and regulates initiation of } \\
\text { transcription. Required for normal mitochondrial } \\
\text { transcription, and for normal assembly of mi- } \\
\text { tochondrial respiratory complexes. Required for } \\
\text { normal mitochondrial function }\end{array}$ \\
\hline PTK2B & $\begin{array}{l}\text { PTK2B protein } \\
\text { tyrosine kinase } 2 \\
\text { beta }\end{array}$ & $\begin{array}{l}\text { Related adhesion focal tyrosine kinase. Non- } \\
\text { receptor protein-tyrosine kinase that regulates re- } \\
\text { organization of the actin cytoskeleton, cell polar- } \\
\text { ization, cell migration, adhesion, spreading and } \\
\text { bone remodeling. Plays a role in the regulation } \\
\text { of the humoral immune response, and is required } \\
\text { for normal levels of marginal B-cells in the spleen } \\
\text { and normal migration of splenic B-cells. Required } \\
\text { for normal macrophage polarization and migra- } \\
\text { tion towards sites of inflammation. Regulates cy- } \\
\text { toskeleton rearrangement and cell spreading in T- } \\
\text { cells, and contributes to the regulation of T-cell } \\
\text { responses. Promotes osteoclastic bone resorption }\end{array}$ \\
\hline DEFA5 & $\begin{array}{l}\text { defensin, al- } \\
\text { pha 5, Paneth } \\
\text { cell-specific }\end{array}$ & $\begin{array}{l}\text { Has antimicrobial activity against Gram-negative } \\
\text { and Gram-positive bacteria. Defensins are } \\
\text { thought to kill microbes by permeabilizing their } \\
\text { plasma membrane }\end{array}$ \\
\hline
\end{tabular}

imsart-aoas ver. 2009/02/27 file: GeneCGH_supplement*_rev.tex date: January 30, 2014 
A. CASSESE ET AL.

Table 1 - continued from previous page

\begin{tabular}{|c|c|c|}
\hline Official gene symbol & Name & Function \\
\hline NPM2 & $\begin{array}{l}\text { nucleophosmin/ } \\
\text { nucleoplasmin, } 2\end{array}$ & $\begin{array}{l}\text { Core histones chaperone involved in chromatin } \\
\text { reprogramming, specially during fertilization and } \\
\text { early embryonic development }\end{array}$ \\
\hline LRP12 & $\begin{array}{l}\text { low density } \\
\text { lipoprotein- } \\
\text { related protein } \\
12\end{array}$ & $\begin{array}{l}\text { This gene encodes a member of the low-density } \\
\text { lipoprotein receptor related protein family. The } \\
\text { product of this gene is a transmembrane protein } \\
\text { that is differentially expressed in many cancer } \\
\text { cells. Alternate splicing results in multiple tran- } \\
\text { script variants }\end{array}$ \\
\hline PPP1R3B & $\begin{array}{l}\text { protein phos- } \\
\text { phatase } 1 \text {, regu- } \\
\text { latory (inhibitor) } \\
\text { subunit 3B }\end{array}$ & $\begin{array}{l}\text { This gene encodes the catalytic subunit of the ser- } \\
\text { ine/theonine phosphatase, protein phosphatase- } 1 \text {. } \\
\text { The encoded protein is expressed in liver and } \\
\text { skeletal muscle tissue and may be involved in reg- } \\
\text { ulating glycogen synthesis in these tissues. This } \\
\text { gene may be a involved in type } 2 \text { diabetes and } \\
\text { maturity-onset diabetes of the young. Alternate } \\
\text { splicing results in multiple transcript variants that } \\
\text { encode the same protein }\end{array}$ \\
\hline MTUS1 & $\begin{array}{l}\text { mitochondrial tu- } \\
\text { mor suppressor } 1\end{array}$ & $\begin{array}{l}\text { This gene encodes a protein which contains a } \\
\text { C-terminal domain able to interact with the an- } \\
\text { giotension II (AT2) receptor and a large coiled- } \\
\text { coil region allowing dimerization. Multiple alter- } \\
\text { natively spliced transcript variants encoding dif- } \\
\text { ferent isoforms have been found for this gene. } \\
\text { One of the transcript variants has been shown to } \\
\text { encode a mitochondrial protein that acts as a tu- } \\
\text { mor suppressor and partcipates in AT2 signaling } \\
\text { pathways. Other variants may encode nuclear or } \\
\text { transmembrane proteins but it has not been deter- } \\
\text { mined whether they also participate in AT2 sig- } \\
\text { naling pathways }\end{array}$ \\
\hline
\end{tabular}

imsart-aoas ver. 2009/02/27 file: GeneCGH_supplement*_rev.tex date: January 30, 2014 
Table 1 - continued from previous page

\begin{tabular}{|c|c|c|}
\hline Official gene symbol & Name & Function \\
\hline NUDCD1 & $\begin{array}{l}\text { NudC domain } \\
\text { containing } 1\end{array}$ & $\begin{array}{l}\text { Chronic myelogenous leukemia tumor antigen } \\
66 \text { Isoform } 1 \text { is the dominant immunogenic iso- } \\
\text { form and is capable of eliciting a humoral re- } \\
\text { sponse in individuals with a variety of solid tu- } \\
\text { mors. Expression of isoform } 1 \text { in a wide variety } \\
\text { of malignancies as well as the presence of an im- } \\
\text { munogenic epitope suggest that it may be a suit- } \\
\text { able target for antigen-specific immunotherapy }\end{array}$ \\
\hline RIMS2 & $\begin{array}{l}\text { regulating synap- } \\
\text { tic membrane ex- } \\
\text { ocytosis } 2\end{array}$ & $\begin{array}{l}\text { Rab effector involved in exocytosis. May act as } \\
\text { scaffold protein regulating synaptic membrane } \\
\text { exocytosis protein } 2\end{array}$ \\
\hline OTUD6B & $\begin{array}{l}\text { OTU domain con- } \\
\text { taining } 6 \mathrm{~B}\end{array}$ & $\begin{array}{l}\text { Deubiquitinating enzymes (DUBs; see MIM } \\
603478 \text { ) are proteases that specifically cleave } \\
\text { ubiquitin (MIM 191339) linkages, negating the } \\
\text { action of ubiquitin ligases. DUBA5 belongs to a } \\
\text { DUB subfamily characterized by an ovarian tu- } \\
\text { mor (OTU) domain }\end{array}$ \\
\hline RP1 & $\begin{array}{l}\text { retinitis pigmen- } \\
\text { tosa } 1 \text { (autosomal } \\
\text { dominant) }\end{array}$ & $\begin{array}{l}\text { Microtubule-associated protein regulating the sta- } \\
\text { bility and length of the microtubule-based ax- } \\
\text { oneme of photoreceptors. Required for the differ- } \\
\text { entiation of photoreceptor cells, it plays a role in } \\
\text { the organization of the outer segment of rod and } \\
\text { cone photoreceptors ensuring the correct orienta- } \\
\text { tion and higher order stacking of outer segment } \\
\text { disks along the photoreceptor axoneme }\end{array}$ \\
\hline LPL & lipoprotein lipase & $\begin{array}{l}\text { Lipoprotein lipase (LPL), like LIPG, is a vascular } \\
\text { lipase, however it is not synthesized in endothelial } \\
\text { cells. It is anchored to the capillary endothelium } \\
\text { by proteoglycans and catalyzes the hydrolysis of } \\
\text { triglycerides to release free fatty acids into the } \\
\text { circulation. LPL therefore initiates the processing } \\
\text { of triglyceride-rich lipoproteins such as chylomi- } \\
\text { crons and VLDL. }\end{array}$ \\
\hline CSMD1 & $\begin{array}{l}\text { CUB and Sushi } \\
\text { multiple domains } \\
1\end{array}$ & $\begin{array}{l}\text { CSMD1 is a novel multiple domain complement- } \\
\text { regulatory protein highly expressed in the central } \\
\text { nervous system and epithelial tissues. }\end{array}$ \\
\hline
\end{tabular}

imsart-aoas ver. 2009/02/27 file: GeneCGH_supplement*_rev.tex date: January 30, 2014 
Table 1 - continued from previous page

\begin{tabular}{|c|c|c|}
\hline Official gene symbol & Name & Function \\
\hline INTS9 & $\begin{array}{lr}\text { integrator } & \text { com- } \\
\text { plex } & \text { subunit } \\
9 & \end{array}$ & $\begin{array}{l}\text { INTS9 is a multiprotein mediator of small nu- } \\
\text { clear RNA processing that associates with the } \\
\text { C-terminal repeat of RNA polymerase II. It is } \\
\text { required for Cell cycle progression but not cell } \\
\text { growth. }\end{array}$ \\
\hline RAB2A & $\begin{array}{l}\text { RAB2A, member } \\
\text { RAS oncogene } \\
\text { family }\end{array}$ & $\begin{array}{l}\text { the RAB2 protein is a resident of pre-Golgi in- } \\
\text { termediates and is required for protein transport } \\
\text { from the endoplasmic reticulum to the Golgi com- } \\
\text { plex. They found that RAB } 2 \text { is essential for the } \\
\text { maturation of pre-Golgi intermediates. }\end{array}$ \\
\hline TG & thyroglobulin & $\begin{array}{l}\text { hyroglobulin provides } 3 \text { things: a thyroid hor- } \\
\text { mone precursor, storage of iodine, and storage of } \\
\text { inactive thyroid hormones. }\end{array}$ \\
\hline CSGALNACT1 & $\begin{array}{l}\text { chondroitin } \\
\text { sulfate } \mathrm{N} \text {-acetyl- } \\
\text { galactosaminyl- } \\
\text { transferase } 1\end{array}$ & $\begin{array}{l}\text { TG expression was decreased in thyroid carcino- } \\
\text { mas but was normal in the other tissues. TSHR } \\
\text { expression was normal in most tissues studied and } \\
\text { was decreased in only some thyroid carcinomas. } \\
\text { In thyroid cancer tissues, a positive relationship } \\
\text { was found between the individual levels of ex- } \\
\text { pression of NIS, TPO, TG, and TSHR. }\end{array}$ \\
\hline TPD52 & $\begin{array}{l}\text { tumor protein } \\
\text { D52 }\end{array}$ & $\begin{array}{l}\text { D52 was expressed at significant levels in some } \\
\text { breast carcinomas but at much lower levels in } \\
\text { breast fibroadenomas. }\end{array}$ \\
\hline ASH2L & $\begin{array}{l}\text { ash2 } \quad \text { (ab- } \\
\text { sent, small, } \\
\text { or homeotic)-like } \\
\text { (Drosophila) }\end{array}$ & $\begin{array}{l}\text { in yeast, the HCF1-associated human } \\
\text { SET1/ASH2 HMT complex possesses his- } \\
\text { tone H3-K4 methylation activity, which activates } \\
\text { transcription. }\end{array}$ \\
\hline DPYS & $\begin{array}{l}\text { dihydropyrimidi- } \\
\text { nase }\end{array}$ & $\begin{array}{l}\text { Dihydropyrimidinase (DPYS), also known as 5,6- } \\
\text { dihydropyrimidine amidohydrolase, or DHP; (EC } \\
\text { 3.5.2.2), is the second enzyme in the 3-step degra- } \\
\text { dation pathway of uracil and thymine after the ac- } \\
\text { tion of dihydropyramidine dehydrogenase }\end{array}$ \\
\hline
\end{tabular}


Table 1 - continued from previous page

\begin{tabular}{|l|l|l|}
\hline Official gene symbol & \multicolumn{1}{|c|}{ Name } & \multicolumn{1}{c|}{ Function } \\
\hline CYP7B1 & $\begin{array}{l}\text { cytochrome P450, } \\
\text { family 7, subfam- } \\
\text { ily B, polypeptide } \\
1\end{array}$ & $\begin{array}{l}\text { The synthesis of primary bile acids from } \\
\text { cholesterol occurs via 2 pathways: the classic } \\
\text { neutral pathway involving cholesterol 7-alpha- } \\
\text { hydroxylase (CYP7A1; 118455), and the acidic } \\
\text { pathway involving a distinct microsomal oxys- } \\
\text { terol 7-alpha-hydroxylase (CYP7B1) }\end{array}$ \\
\hline \hline
\end{tabular}

\section{References.}

S. Guha, Y. Li, and D. Neuberg. Bayesian hidden Markov modelling of array cgh data. JASA, 103: 485-497, 2008.

$\begin{array}{ll}\text { DEPARTMENT OF STATISTICS } & \text { DEPARTMENT OF BIOSTATISTICS } \\ \text { RICE UNIVERSITY } & \text { MD ANDERSON CANCER CENTER } \\ \text { HOUSTON, TEXAS 77005 } & \text { HOUSTON, TEXAS 77030 } \\ \text { USA, } & \text { USA, } \\ \begin{array}{l}\text { E-MAIL: Alberto.Cassese@ rice.edu } \\ \text { marina@ rice.edu }\end{array} & \text { E-MAIL: mguindani@mdanderson.org } \\ \text { DEPARTMENT OF MATHEMATICS AND STATISTICS } & \text { CENTER OF COMPUTATIONAL BIOLOGY AND MODELLING (CCMB) } \\ \text { GEORGETOWN UNIVERSITY } & \text { INSTITUTE OF INTEGRATIVE BIOLOGY } \\ \text { WASHINGTON, DC } 20057 & \text { UNIVERSITY OF LIVERPOOL } \\ \text { USA, } & \text { LIVERPOOL } \\ \text { E-MAIL: mgt26@georgetown.edu } & \text { UK, } \\ & \text { E-MAIL: f.falciani@ liverpool.ac.uk }\end{array}$

